\title{
ENHANCING CAREER COMMITMENT: THE INFLUENCE OF HUMAN RESOURCE MANAGEMENT PRACTICES
}

\author{
Khulida Kirana Yahya* \\ Universiti Utara Malaysia \\ Fee-Yean Tan \\ Universiti Utara Malaysia
}

\begin{abstract}
The purpose of this study is to examine the relationship between human resource management (HRM) practices (training and development, compensation and promotion) with career commitment. Data was gathered through questionnaire from 253 employees of a multinational company in Malaysia. The regression results indicated that compensation, and training and development were significant predictors to enhance career commitment. The results also suggested that compensation was the most important factor that influence career commitment followed by training and development.
\end{abstract}

Keywords: Career Commitment; HRM Practices; Training and Development; Compensation; Promotion.

\section{INTRODUCTION}

The manufacturing sectors in Asia have faced challenging task to keep talents for their continuous growth and expansion. Hence, keeping the right talented employees is not an easy task. It involves a complex process of designing HRM practices. Many skill sets might not be transferable between industries as different industries require specific skill sets which can be quite different. As such, it is reasonable to assume that different approaches are required to attract, retain and motivate employees.

A core belief in human resources is to retain and develop employees to obtain competitive advantage. In order to retain valuable employees, it has become necessary for organizations to transform from using an employee controlling method to a more employee career commitment driven strategy. To gain employees' career commitment to the organization and increase retention, the employer needs to identify which HRM factors that will influence their career commitment.

Research evidence (Armstrong-Stassen \& Cameron, 2005; Minbaeva, 2008; Shipley \& Kleiner, 2005; Uen \& Chien, 2004) revealed that compensation, training and development are important HRM practices for an organization to generate a pool of motivated, competent and high performance employees that can be a significant factor of an organization's

* Corresponding author: Khulida Kirana Yahya, School of Business Management, College of Business, Universiti Utara Malaysia, 06010 UUM Sintok, Kedah, Malaysia. Phone: +604-9287521. Fax: +6049287422. E-mail: khulida@uum.edu.my 
competitive advantage. Nabi (2003) stated that employees' career commitment is influenced by the employees' perceptions and attitudes toward their organization's HRM practices. He stressed that those employees who have positive perception toward an organization's HRM practices will be more motivated and committed to the organization. Evidence has shown that employees who are committed to their career enjoy relatively high positive career outcomes. Therefore, enhancing career commitment should be an important objective for those who desire to enhance their career achievement, and these will be influenced by their perceptions towards organizational HRM practices.

Without denying the importance of HRM practices on employees' career commitment, this paper examines the relationship between individual perceptions of organizational HRM practices (specifically on compensation, training and development, and promotion) and career commitment. With the aim that this study can assist employers to better understand how employees' perceptions influence their career commitment. In addition, the findings of this study will also add knowledge to the examined company's management practices by developing and rewarding employees who are capable of aligning work performance with the standards set by the management.

\section{CAREER COMMITMENT}

Employee career commitment has been defined as a mindset which ties the individual to an organization. Vandenberg and Scarpello (2004) define "career commitment" as a person's belief in and acceptance of the value of his or her chosen occupation or line of work and willingness to maintain membership in a particular occupation.

Career commitment is characterized by the development of personal career goals, the attachment to, identification with, and involvement in those goals. Career commitment should exceed occupations or jobs (Hall, 1976). Career commitment involves self-generated goals and commitment to one's own career, which may lead to employment in several organizations.

People who are committed to their careers should also experience more career success than those who are less committed. Committed individuals should be prepared to make significant investments in their careers. The study by Colarelli and Bishop (1990) found that people who are committed to their career will be more likely to set high career goals for themselves and put forth effort as well as continue to pursue these goals even in the face of obstacles and setbacks. Previous researchers (Bandura, 1986; Greenhaus \& Parasuraman, 1993; Locke \& Latham, 1990a; 1990b) also suggested that greater effort and perseverance generally lead to high performance, and this high performance, in turn, will result in positive outcomes such as higher salaries or promotions as well as self-satisfaction.

\section{HRM PRACTICES}

At the organization level, HRM practices have been identified as a source of business revenues (Mathis \& Jackson, 2004). This is because HRM practices such as compensation (offer attractive rewards to attract and retain skilled manpower), promotion (opportunity for career advancement), and training and development (trained potential employees to undertake higher-grade tasks) have been considered as the base strategies to ensure organizations have a 
group of talented employees that can assist in increasing organizational productivity. However, from the employees' perspective, HRM practices are recognized as the organization's effort in supporting their career development (Armstrong-Stassen \& Cameron, 2005). This is because most of the employees have assumed that it is the organization's obligations to design a wide range of HRM policies and programs to assist them to perform the job effectively as the reward of their contribution to work. Researches (Armstrong-Stassen \& Cameron, 2005; Khilji \& Wang, 2007; Poon, 2004) indicated that employees' career commitment depends on their perception toward the organization's effort in supporting their career development needs. If employees perceive the organization are not valuing their contribution and showing little concern in supporting their development needs, they may be less committed to their job.

\subsection{Compensation}

Compensation is the total financial or non-financial rewards payable to an employee in return for their services (Milkovich \& Newman, 2005). The rewards are usually given based on the value of job, level of personal involvement, efforts, and performance (Milkovich \& Newman, 2005). Therefore, it has become an essential responsibility for every employer to reward employees for their contributions or effort to the organization in a fair and equitable manner.

Compensation offers an opportunity for security, autonomy, recognition and an improved selfworth (Hoyt \& Gerdloff, 1999). These increased feelings of self-worth and importance should lead to effective commitment. The studies of Igbaria and Greenhaus (1991; 1992), and Mathieu and Zajac (1990) revealed that salary is related to career commitment. It should be noted that when a career is rewarding, either in monetary terms or prestige (highly valued by the society), an employee in an organization may be committed to it. Bozionelos (1996) supports this assertion by suggesting that compensation is the only variable that significantly influences employees' career commitment. The reason being that, employees will feel their contributions to work is appreciated by the organization through the remunerations they receive. This feeling can influence their behaviours, i.e. career commitment.

In addition to that, previous researchers (Day \& Allen, 2004; Lee et al., 2000) suggested that employees' career commitment will be increased if they are getting salary increment. It was indicated that employees who received high pay will be more strongly committed to their career. Following the above discussion, it is hypothesized that:

H1: Employees' perception towards organizational compensation policies will influence their career commitment.

\subsection{Training and development}

Training and development is the formal activities designed by organization to help employees acquire the necessary skills and knowledge to perform current or future jobs (Mondy \& Noe, 2005). Training and development had been considered as one of the crucial activities of human capital development (Mathis \& Jackson, 2004). This is because training and development activities such as on-the-job training, mentoring, coaching, and counselling are important activities for employees to get valuable supports, knowledge, skills and abilities that may enhance their employability and marketability in an organization. Thus, training and 
development is an important factor in the career commitment of employees throughout their career lives. This point has been supported by Aryee and Tan (1992) study. Their research found that employees who were committed to their profession did so to keep up with new developments in the profession by attending additional training programs.

Hence, the organizational training and development programs may also influence the employees' psychological states (i.e. career commitment). Employees' career commitment will be increased if they believe that the organization is willing to provide training and development programs. The reason being that, when employees have positive perception towards the organizational training and development policies, they feel that the organization is concerned with their development needs, and this perception will influence them to be more committed to their work. Hence, it is postulated that:

H2: Employees' perception towards organizational training and development policies will influence their career commitment.

\subsection{Promotion}

Career commitment reflects a form of work commitment that the employees have towards their careers. Individuals with a strong degree of career commitment and higher levels of career expectations may make significant investments in their careers (Aryee \& Tan, 1992). As such, they should be willing to commit to the efforts needed to attain career goals through with which they expect to have opportunities for advancement.

It has been shown that employees are more committed to an organization when they believe that the company pursues a promotion from within (PFW) policy (Gaertner \& Nollen, 1989). By implementing promotion from within (PFW), employees may feel less uncertainty regarding the future of their career in the company and become more motivated to commit to their careers. Employees will feel satisfied because their efforts are rewarded (i.e. getting promoted to higher position) by the organization. Therefore, they will be more committed to their work as the organization will offer promotion opportunities to them as rewards of their hard-work. Following the above discussion, this study hypothesizes that:

H3: Employees' perception towards organizational promotion policies will influence their career commitment.

\section{RESEARCH FRAMEWORK}

Figure 1 proposes the research framework which consists of the independent variable (HRM practices) and the dependent variable (career commitment). There is a direct relationship between dimensions of HRM practices and career commitment. As proposed by the Social Cognitive Career Theory (SCCT), career outcomes (i.e. career commitment) are influenced by individual perception towards organizational events such as organizational HRM practices (Brown, 2003; Lent \& Brown, 1996; 2006; Zikic \& Saks, 2009). In line with the proposition of SCCT, the research framework (Figure 1) also suggests that employees' perception on organizational HRM practices, such as compensation, training and development, and promotion are primary influence on their level of career commitment. 
Figure 1: Research Framework of the Relationship between HRM Practices and Career Commitment

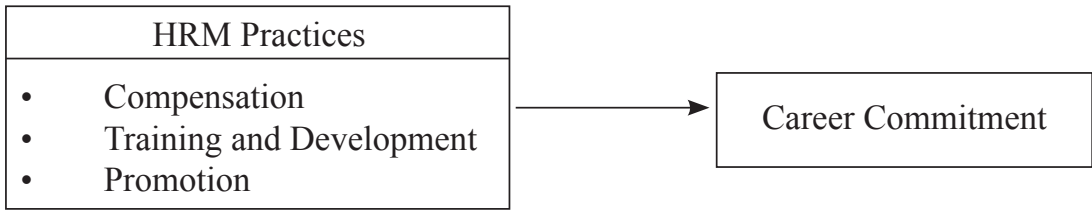

\section{METHOD}

\subsection{Samples}

Table 1: Respondents' Demographic Characteristic

\begin{tabular}{|c|c|c|}
\hline Demographic Characteristic & Frequency & Percentage $(\%)$ \\
\hline \multicolumn{3}{|l|}{ Gender } \\
\hline Male & 219 & 86.6 \\
\hline Female & 34 & 13.4 \\
\hline \multicolumn{3}{|l|}{ Race } \\
\hline Malay & 164 & 64.8 \\
\hline Chinese & 60 & 23.7 \\
\hline Indian & 29 & 11.5 \\
\hline \multicolumn{3}{|l|}{ Education Level } \\
\hline SPM/STPM & 9 & 3.6 \\
\hline Diploma & 88 & 34.8 \\
\hline Bachelor Degree & 56 & 22.1 \\
\hline Master Degree & 92 & 36.4 \\
\hline $\mathrm{PhD}$ & 8 & 3.2 \\
\hline \multicolumn{3}{|l|}{ Length of Services } \\
\hline Less than 6 month & 4 & 1.6 \\
\hline $6-12$ month & 55 & 21.7 \\
\hline 1 to 3 years & 149 & 58.9 \\
\hline More than 4 years & 45 & 17.8 \\
\hline \multicolumn{3}{|l|}{ Age } \\
\hline Less than 25 years & 13 & 5.1 \\
\hline $25-35$ years & 61 & 24.1 \\
\hline $36-45$ years & 67 & 26.5 \\
\hline $46-55$ years & 109 & 43.1 \\
\hline More than 56 years & 3 & 1.2 \\
\hline
\end{tabular}

Note: $\mathrm{n}=253$ 
The population of this study is the 700 middle and lower level employees of a manufacturing company located in Malaysia. According to the sample determination table provided by Sekaran (2006), the appropriate sample size for a population of 700 is 258 (n). Thus, 258 questionnaires were distributed. The response rate was 98\% (253 returned and usable for further analysis).

As shown in Table 1, the respondents included 219 men and 34 women. Most of the respondents were Malays (64.8\%), and the majority of respondents' age ranged between 46 - 55 years old (43.1\%). In terms of educational achievement, 92 respondents $(36.4 \%)$ had a Master's degree, while 88 respondents $(34.8 \%)$ were Diploma holders. Besides that, 159 of the respondents $(62.8 .0 \%)$ did not have any professional qualification. The majority of the respondents $(58.9 \%)$ indicated that they have worked in their current company between 1 to 3 years.

\subsection{Measurements}

The career commitment scale designed by Ellemers et al. (1998) was adapted for the study. These items were widely used in previous empirical studies with a consistent reliability result of 0.88. In terms of compensation, the Heneman and Schwab (1985) Pay Satisfaction Questionnaire (PSQ) were adapted. Meanwhile, training and development was measured by the instrument adapted from Rogg et al. (2001). However, items developed by Greenhaus et al. (1990) were adapted for the measurement of promotion. All responses were on 5-point Likert scale and ranged from (1) 'Strongly disagree' to (5) 'Strongly agree'.

\section{RESULTS}

Means, standard deviations, and Pearson correlations of the variables are shown in Table 2. There were positive relationships between compensation, training and development, promotion and career commitment. Besides that, the reliability results that indicated the overall Cronbach's alpha values for compensation, training and development and promotion were $0.80,0.83$ and 0.85 respectively. Meanwhile, the Cronbach's alpha for career commitment was 0.81 .

To determine the dimensions of HRM practices that influence career commitment, regression analysis was performed. Table 3 indicated that $49 \%(\mathrm{R} 2=0.49)$ of the variance in career commitment had been significantly explained by compensation, training and development, and promotion. The results also showed that compensation $(\beta=0.848, \mathrm{p}<0.01)$ was the important factor in explaining career commitment compared to training and development $(\beta=-0.261, \mathrm{p}$ $<0.01)$. However, promotion was not significant in predicting career commitment. Therefore, hypothesis one (H1) and two (H2) are accepted while hypothesis three (H3) is rejected.

Table 2: Reliability, Means, Standard Deviations and Correlations of the Study Variables

\begin{tabular}{lccccccc}
\hline Variables & $\boldsymbol{\alpha}$ & $\mathbf{M}$ & SD & $\mathbf{1}$ & $\mathbf{2}$ & $\mathbf{3}$ & $\mathbf{4}$ \\
\hline 1. Career commitment & 0.81 & 2.31 & 1.99 & 1 & & & \\
2. Compensation & 0.80 & 3.65 & 0.54 & $0.65^{* *}$ & 1 & & \\
3. Training and development & 0.83 & 1.95 & 0.13 & $0.31^{* *}$ & $0.41^{* *}$ & 1 & \\
4. Promotion & 0.85 & 2.22 & 0.19 & $0.29^{* *}$ & $0.61^{* *}$ & $0.45^{* *}$ & 1 \\
\hline
\end{tabular}

Notes: $\mathrm{n}=253 ; * * \mathrm{p}<0.01 ; \alpha=$ alpha reliability values, $\mathrm{M}=$ mean, $\mathrm{SD}=$ standard deviation 
Table 3: Multiple Regressions Results of HRM Practices on Career Commitment

\begin{tabular}{lccccc}
\hline & \multicolumn{3}{c}{ Unstandardized Coefficients } & \multicolumn{3}{c}{ Standardized Coefficients } \\
\cline { 2 - 6 } & Beta & Std. Error & Beta & t & Sig. \\
\hline (Constant) & 2.180 & .144 & & 15.133 & .000 \\
Compensation & .311 & .022 & .848 & 14.061 & $.000^{* *}$ \\
Training \& development & -.388 & .079 & -.261 & -4.893 & $.000^{* *}$ \\
Promotion & -.110 & .059 & -.108 & -1.853 & .065 \\
$\mathrm{R}^{2}=.49$ & & & & & \\
$\mathrm{~F}=79.85^{* *}$ & & & & & \\
\hline
\end{tabular}

Notes: $* * \mathrm{p}<0.01$

\section{DISCUSSION}

The results reveal that there were significant associations between HRM practices (compensation and training and development) and career commitment. However, promotion does not indicate significant relationship with career commitment. The result indicated that a person's belief in and acceptance of the value of his or her chosen occupation or line of work and willingness to maintain membership in a particular occupation is very much related to the compensation and also training and development practices provided by the organization.

The results (Table 3) indicated that employees were satisfied with the remuneration received. This means employees had positive perception towards the organizational compensation policies, where they found that the organization had administrated equitable compensation policies within the organization. Fairness in the compensation allocation had reflected that all employees' contribution to work had been justly rewarded. Furthermore, this perception had influenced employees to be more committed towards their career. This result is supported by Higginbotham (1997), Kochanski and Ledford (2001), in which they also found that employees career commitment is influenced by the organizational compensation policies.

On the other hand, although previous studies (Irving et al., 1997; Meyer et al., 1993; Tomlinson, 2002) indicated that training and development was positively correlated with career commitment, this study found opposite result. The regression results (Table 3) indicated that employees who have higher perception of training and development are likely to express lower level of career commitment. This could be explained by the fact that examined company had offered variety of training and development programs to employees, but, employees faced difficulty to transfer what they had learned into practice. Hence, employees had perception that the skills and knowledge learned from the training and development programs did not guarantee their career commitment towards the organization.

The regression results as depicted in Table 3 indicated that employees who have higher perception of promotion are not likely to express higher level of career commitment. One probable explanation may lie in the fact that most of the employees in the examined organization felt that their career commitment was not interfered by the organizational promotion policy, but was influenced by the amount of compensation, and training and development programs received or attended. Employees perceived compensation policies that can fairly reward their 
hard-work through salary increment to be the main factor in influencing their level of career commitment. The reason being, employees had the perception that, if they are promoted to a higher position, they would have greater responsibility and workload. This can create job stress, resulting in less commitment. However, with the salary increment, employees can still assume similar job responsibilities and workload, without creating further job stress. Hence, employees are more likely to experience high level of career commitment through the salary received compared to promotion opportunities.

\section{CONCLUSION}

This study has determined the relationship between HRM practices and career commitment. The study revealed that HRM factors of compensation and training and development were associated with career commitment. Thus it can be indicated that compensation and training and development is related to the development of personal career goals, attachment, identification and involvement of the career goals. Employees believe that compensation and training and development practices being the reason of their willingness to stay and committed to the career. Hence, in order for organizations to capitalize their employees, they need to emphasize on HRM practices to influence employees' career commitment. HRM practices regarding compensation and training and development need to be revised to cater for the needs of the employees so that they stay committed to the career and to the organization. However, these findings are only applicable to employees in the company under study. A suggestion for future research is to examine the relationship of other HRM practices and career commitment across companies and industries.

\section{REFERENCES}

Armstrong-Stassen, M., \& Cameron, S. (2005). Factors related to the career satisfaction of older managerial and professional women. Career Development International, 10(3), 203-215.

Aryee, S., \& Tan, K. (1992). Antecedents and outcomes of career commitment. Journal of Vocational Behaviour, 40(3), 288-305.

Bandura, A. (1986). Social foundations of thought and action: A social-cognitive view. Englewood Cliffs, New Jersey: Prentice-Hall.

Bozionelos, N. (1996). Organizational promotion and career satisfaction. Psychological Reports, $79(2), 371-375$.

Brown, D. (2003). Career information, career counselling, and career development ( $8^{\text {th }}$ ed.). USA: Pearson Education.

Colarelli, S. M., \& Bishop, R. C. (1990). Career commitment: Functions, correlates, and management. Group and Organizational Studies, 15(2), 158-76.

Day, R., \& Allen, T. D. (2004). The relationship between career motivation and self-efficacy with protégé career success. Journal of Vocational Behavior, 64(1), 72-91.

Ellemers, N., Gilder, D., \& Heuvel, H. (1998). Career oriented versus team oriented commitment and behavior at work. Journal of Applied Psychology, 83(5), 717-30. 
Gaertner, K., \& Nollen, S. (1989). Career experiences, perceptions of employment practices, and psychological commitment to the organisation. Human Relations, 42(11), 975-991.

Greenhaus, J. H., \& Parasuraman, S. (1993). Job performance attributions and career advancement prospects: An examination of gender and race effects. Organizational Behavior and Human Decision Processes, 55(2), 273-97.

Greenhaus, J. H., Parasuraman, S., \& Wormley, W. M. (1990). Effects of race on organizational experiences, job performance evaluations, and career outcomes. Academy of Management Journal, 33(1), 64-86.

Hall, D. T. (1976). Organization commitment: Theory, research, and measurement. Unpublished manuscript, Northwestern University.

Heneman, H. G. III., \& Schwab, D. P. (1985). Pay satisfaction: Its multidimensional nature and measurement. International Journal of Psychology, 20(2), 129-141.

Higginbotham, J. S. (1997). The satisfaction equation. Research \& Development, 39(10), 1-9.

Hoyt, J., \& Gerdloff, E. A. (1999). Organisational environment, changing economic conditions and the effective supervision of technical personnel: A management challenge. Journal of High Technology Management Research, 10(2), 275-294.

Igbaria, M., \& Greenhaus, J. (1992). Determinants of MIS employees' turnover intentions: A structural equation model. Communications of the ACM, 35(2), 34-49.

Igbaria, M., \& Greenhaus, J. H. (1991). Career orientations of MIS employees: An empirical analysis. MIS Quarterly, 15(2), 151-170.

Irving , P. G., Coleman, D. F., \& Cooper, C. L. (1997). Further assessment of a three component model of occupational commitment: Generalizability and differences across occupations. Journal of Applied Psychology, 82(3), 444-452.

Khilji, S. E., \& Wang, X. (2007). New evidence in an old debate: Investigating the relationship between HR satisfaction and turnover. International Business Review, 16(3), 377-395.

Kochanski, J., \& Ledford, G. (2001). How to keep me - Retaining technical professionals. Research Technology Management, 44(3), 31-38.

Lee, K., Carswell, J. J., \& Allen, N. (2000). A meta-analytic review of occupational commitment: Relations with person and work-related variables. Journal of Applied Psychology, 85(5), 799-811.

Lent, R. W., \& Brown, S. D. (1996). Social cognitive approach to career development: an overview. The Career Development Quarterly, 44(4), 310.

Lent, R. W., \& Brown, S. D. (2006). Integrating person and situation perspectives on work satisfaction: A social cognitive view. Journal of Vocational Behavior, 69(2), 236-247.

Locke, E. A., \& Latham, G. P. (1990a). A Theory of Goal Setting and Task Performance. Englewood Cliffs, New Jersey: Prentice-Hall. 
Locke, E. A., \& Latham, G. P. (1990b). Work motivation and satisfaction: Light at the end of the tunnel. Psychological Science, 1(4), 240-6.

Mathieu, J. E., \& Zajac, D. (1990). A review and meta-analysis of the antecedents, correlates, and consequences of organizational commitment. Psychological Bulletin, 108(2), 171-94.

Mathis, R. L., \& Jackson, J. H. (2004). Human resource management (10 ${ }^{\text {th }}$ ed.). Singapore: Thomson Learning.

Meyer, J. P., Allen, N. J., \& Smith, C. A. (1993). Commitment to organisations and occupations: Extension and test of three component conceptualisation. Journal of Applied Psychology, 78(4), 538-551.

Milkovich, G. T., \& Newman, J. M. (2005). Compensation ( $8^{\text {th }}$ ed.). Boston: McGraw-Hill.

Minbaeva, D. B. (2008). HRM practices affecting intrinsic and extrinsic motivation of knowledge receivers and their effect on intra-MNC knowledge transfer. International Business Review, 17(6), 703-713.

Mondy, R. W., \& Noe, R. M. (2005). Human resource management (9 $9^{\text {th }}$ ed.). New Jersey: Pearson Education.

Nabi, G. R. (2003). Situational characteristics and subjective career success: The mediating role of career enhancing strategies. International Journal of Manpower, 24(6), 653-672.

Poon, J. M. L. (2004). Effects performance appraisal politics on job satisfaction and turnover intention. Personnel Review, 33(3), 322-334.

Rogg, K. L., Schmidt, D. B., Shull, C., \& Schmitt, N. (2001). Human resources practices, organizational climate and customer satisfaction. Journal of Management, 27(4), 431449.

Sekaran, U. (2006). Research method for business: A skill building approach (4 ${ }^{\text {th }}$ ed.). USA: Wiley.

Shipley, C. J., \& Kleiner, B. H. (2005). Compensation management of commissioned sales Employees. Management Research News, 28(2/3), 2-10.

Tomlinson, A. (2002). High technology workers want respect: Survey. Canadian Human Resources Reporter, 15(3), 2.

Uen, J. F., \& Chien, S. H. (2004). Compensation structure, perceived equity and individual Performance of R\&D professionals. Journal of American Academy of Business Cambridge, 4(1/2), 401-405.

Vandenberg, R. J., \& Scarpello, V. (2004). A longitudinal assessment of the determinant relationship between employee commitments to the occupation and the organization, Journal of Organizational Behaviour, 15(6), 535-47.

Zikic, J., \& Saks, A. M. (2009). Job search and social cognitive theory: The role of careerrelevant activities. Journal of Vocational Behaviour, 74(1), 117-127. 